2. To: (Receiving Organization)

Distribution

5. Proj./Prog./Dept./Div.:

WESF Decoupling Project

8. Originator Remarks:

This document is an Engineering Study providing information for the volumetric airflow reduction in the WESF $\mathrm{K}-3$ exhaust system.

11. Receiver Remarks: 11A. Design Basel ine Document? [] Yes [X] No

\begin{tabular}{l|c} 
3. From: (Originating Organization) & $\begin{array}{l}\text { 4. Related EDT No.: } \\
\text { WESF Capsule Management }\end{array}$ \\
\hline $\begin{array}{l}\text { 6. Design Authority/ Design Agent/Cog. } \\
\text { Engr.: }\end{array}$ & $\begin{array}{l}\text { 7. Purchase Order No.: } \\
\text { T. Gainey }\end{array}$ \\
\hline
\end{tabular}

9. Equip./Component No.:

$\mathrm{N} / \mathrm{A}$

10. System/Bldg./Facility: HVAC/225-B/WESF

12. Major Assm. Dwg. No.: $N / A$

13. Permit/Permit Application No_: $\mathrm{N} / \mathrm{A}$

14. Required Response Date: $N / A$

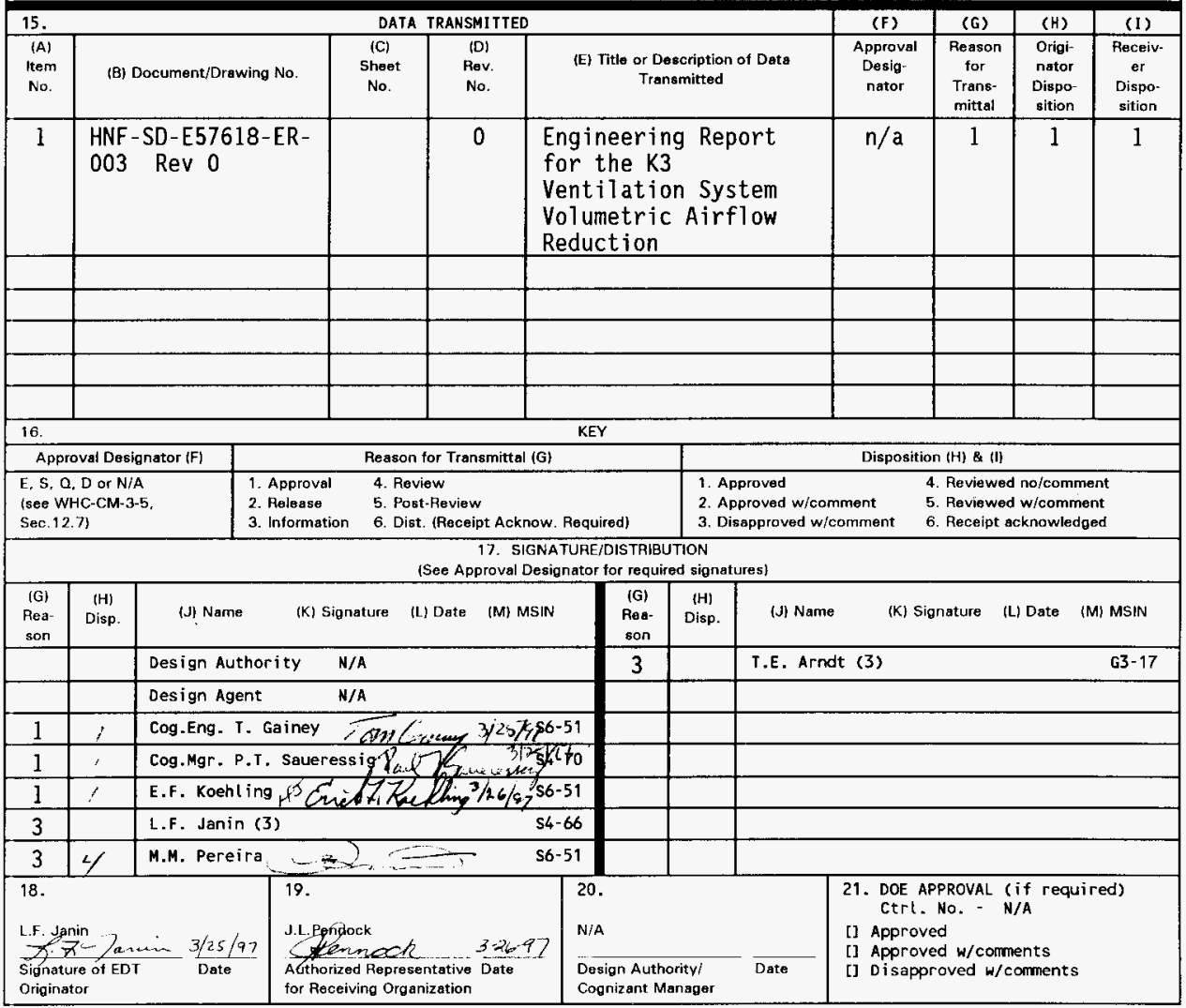




\section{Engineering Report for the K3 Ventilation System Volumetric Airflow Reduction}

Timothy E. Arndt

Fluor Daniel Northwest, Richland, WA 99352

U.S. Department of Energy Contract DE-AC06-96RL13200

EDT/ECN: $621132 \quad$ UC: 630

Org Code: $04 \mathrm{E00}$ Charge Code: E57618

B\&R Code: EW7050000 Total Pages: 22

Key Words: WESF, Hot Cells, Ventilation System, Airflow Reduction

Abstract: This engineering report will discuss the ventilation tasks necessary for minimizing the current $K 3$ ventilation systems volumetric airflows while continuing to maintain negative pressures in both the canyon area and the related hot cells, assuring radiological confinement and containment of WESF.

TRADEMARK DISCLAIMER. Reference herein to any specific commercial product, process, or service by trade name, trademark, manufacturer, or otherwise, does not necessarily constitute or imply its endorsement, recommendation, or favoring by the United States Government or any agency thereof or its contractors or subcontractors.

Printed in the United States of America. To obtain copies of this document, contact: Document Control Services, P.0. Box 950, Mailstop H6-08, Richland WA 99352, Phpan_5no) 372-2420. Fax (509) 376-4989.
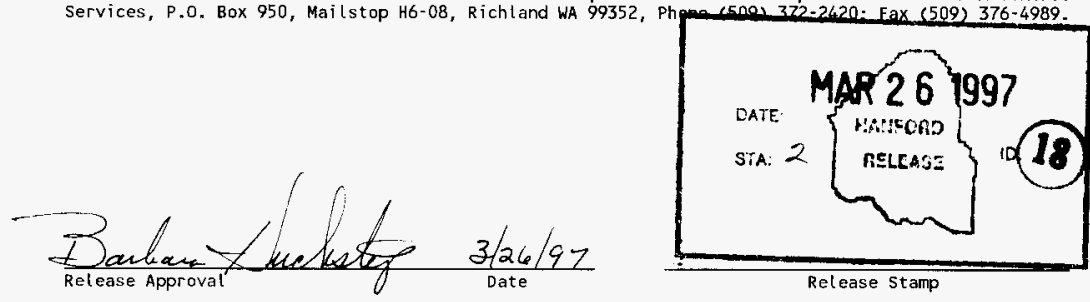

Release Stamp

\section{Approved for Public Release}




\section{ENGINEERING REPORT \\ ENGINEERING REPORT FOR THE K3 VENTILATION SYSTEM VOLUMETRIC AIRFLOW REDUCTION}

\section{E57618}

Prepared for the U.S. Department of Energy Assistant Secretary of Environmental Management

Project Hanford Management Contractor for the

Approved for public release; distribution is unlimited 
FOR

\title{
ENGINEERING REPORT FOR THE K3 VENTILATION SYSTEM VOLUMETRIC AIRFLOW REDUCTION
}

\author{
WORK ORDER E57618
}

Prepared by

Fluor Daniel Northwest

Richland, Washington

for

B\&W Hanford Company

Richland, Washington
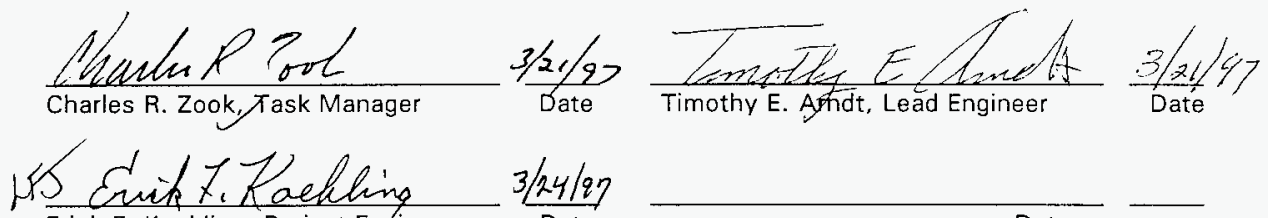

Erick F. Koehling, Project Engineer

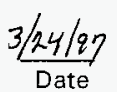

Date 


\section{CONTENTS}

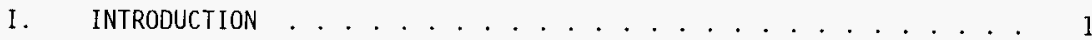

II. PURPOSE ............................ 1

III. SUMMARY ........................... I

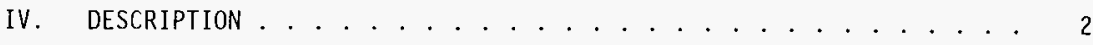

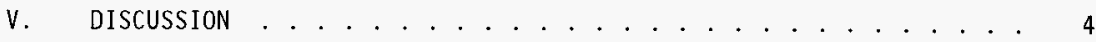

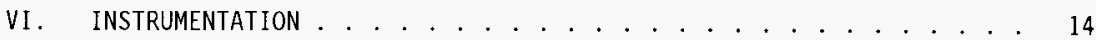

VII. ASSUMPTIONS . . . . . . . . . . . . . . . . . . . . . . . . 14

VIII. REFERENCES ......................... . . 15

\section{FIGURES}

1. WESF HVAC K3 System Existing Conditions ............ 16

2. WESF HVAC K3 System Proposed Reduced Airflow. . . . . . . . . 17

3. Plan - WESF Hot Cells ................. 18 


\title{
ENGINEERING REPORT
}

\section{ENGINEERING REPORT FOR THE K3 VENTILATION SYSTEM VOLUMETRIC AIRFLOW REDUCTION}

\author{
E57618
}

\section{INTRODUCTION}

The 225-B Waste Encapsulation Storage Facility (WESF) is located in the northwest quadrant of the 200 East Area. WESF was designed to package and store waste stream products, cesium, and strontium that are doubly encapsulated in metal containers and stored for an interim period under $13 \mathrm{ft}$ of water. Radiological containment and confinement features are incorporated into the various parts of WESF and support systems to protect personnel and the general public from excessive radiation exposure and/or contamination. WESF has a continued mission for storage of cesium and strontium capsules.

\section{PURPOSE}

This engineering report will discuss the ventilation tasks necessary for minimizing the current $K 3$ ventilation systems volumetric airflows while continuing to maintain negative pressures in both the canyon area and the related hot cells, assuring radiological confinement and containment of WESF.

\section{SUMMARY}

The $\mathrm{K} 3$ exhaust airflow should be reduced to approximately $3,000 \mathrm{cfm}$ for normal operation. Exhaust fans K 3-7-1 and K3-7-2 should be modified with a new fan wheel and motor to correspond to the $3,000 \mathrm{cfm}$ airflow rate at a calculated static pressure. Preliminary assumption of 17 -in. water gage ( $\mathrm{wg}$ ) appears to be adequate for the exhaust system. Formal calculations should be performed prior to selecting a new fan wheel and motor.

Decontamination of the WESF hot cells for the minimization of HEPA filter replacement is not required. 
The in-cell HEPA filters should be replaced with clean filters and then isolated from the exhaust system with the exception of $F$ and $G$ cells which would not be isolated but would be maintained at the current airflow. The other process cells would cascade into A cell and then exhaust through A cell filters. The chilled water coils to the cells and the $\mathrm{K} 3$ supply system should be isolated in-place and drained. An engineering study should be performed to determine the feasibility of replacing the $\mathrm{K} 3$ below grade remote handling HEPA filters with an above grade HEPA filter housing at the reduced airflow rate. The housing should have the capability of bag in and bag out HEPA filters.

Supply fan K3-6-1 can be reduced to approximately $2,500 \mathrm{cfm}$; the steam coil can be replaced with an electric heater to maintain an inside temperature of $45^{\circ} \mathrm{F}$. An electric heating coil of approximately $100 \mathrm{~kW}$ may be required; the energy consumption saved by reducing the exhaust fans horsepower can be applied to the electrical resistance heating. Calculations will be required to correctly size and determine heating requirements. WESF is expected to be in operation until the year 2017; therefore, a temporary heating system was not considered.

An operating test procedure (OTP) should be prepared to empirically test the system at the reduced airflows prior to actual modifications to the ventilation system to assure that all facility criteria will be attained.

One of the main advantages of having the volumetric airflow reduced is the savings in the fan motor horsepower due to the smaller motor sizes, and the greater span between the required time for the replacement of the HEPA filters. If necessary to determine the cost saved, a cost analysis would be required.

The existing stack isokinetic probe will require replacement with a new probe sized for the correct volumetric airflow.

\section{DESCRIPTION}

\section{Existing $K 3$ Ventilation System}

The $\mathrm{K} 3$ ventilation system provides ventilation for the process cells and canyon area of the WESF (see Figure 1). The $K 3$ ventilation systems are comprised of both a supply system and an exhaust system. The supply system is located in the HVAC room of the WESF; the exhaust system is located outside, southwest of WESF. The $\mathrm{K} 3$ filters are located below grade in a filter pit. 
The supply system is enclosed in a housing comprised of electric infrared heater, prefilters, steam preheat coils, chilled water coils, and steam reheat coils maintaining set point temperatures both in the winter and summer months. The supply fan is rated at $6,550 \mathrm{cfm}$ of standard air, at $3-\mathrm{in}$. wg with a $7.5 \mathrm{hp}$ electric motor. The supply ductwork is routed on the roof of WESF and penetrates the canyon roof through four ducts that supply air directly to the canyon via diffusers. From the canyon, the air enters the process cells via stainless steel ductwork embedded in the canyon floor.

Air then exits the canyon through two paths. The first path is through an exhaust duct that runs the length of the south wall of the canyon. The second path is through the process cells.

The ductwork to the process cells is not directly connected to the $\mathrm{K} 3$ supply fan. The supply air via the ductwork is drawn into each cell by the negative pressure in the cells created by the $K 3$ exhaust system. Each process cell is equipped with two (2) 24 -in. by 24-in. by 11-1/2-in. HEPA filter, and two (2) chilled water coils with butterfly valves.

The $\mathrm{K} 3$ exhaust system allows the canyon and process cells to maintain set point negative pressures. The air is exhausted from the canyon through exhaust grilles attached to ductwork mounted on the south wall of the canyon and routed to a duct under the truckport floor which then is routed to the K3 HEPA filters.

Air exits the process cells through HEPA filters. Each cell has two individual ducts that are each equipped with a 12-in. by 12-in. by 11-1/2-in. single HEPA filter and a butterfly valve. The process air from the cells is exhausted to a duct located below the cell floor and is routed under the truckport floor, exits WESF, continues to the K3 filters and is discharged into the atmosphere via a stack.

The K3 HEPA filter system has two individual systems: an east bank and a west bank. When one bank is in operation, the other is in standby mode. Each bank is comprised of a de-entrainer assembly that consists of chevron moisture eliminators (vane impingement), two moisture separators, and two electric heaters. The air enters the de-entrainer assembly horizontally and leaves the de-entrainer vertically. From the de-entrainer, the air passes through two stages of HEPA filters, each stage contains six 24-in. by $24-i n$. by $11-1 / 2$-in. filters. The air is routed to the exhaust stack via exhaust fan $\mathrm{K} 3-7-1$ or $\mathrm{K} 3-7-2$ and then is discharged into the atmosphere.

\section{Original Design Airflows}

The original design required approximately 6,875 cubic feet per minute (cfm) of standard air be exhausted from the canyon and the process cells. Of the $6,875 \mathrm{cfm}$, the maximum volumetric airflow from the canyon is approximately $5,125 \mathrm{cfm}$ (this 
amount occurs when the minimum volumetric airflow of $1,750 \mathrm{cfm}$ is exhausted through the process cells); the minimum airflow through each cell is $250 \mathrm{cfm}$. The minimum volumetric airflow through the canyon is $3,375 \mathrm{cfm}$ (this amount occurs when the maximum volumetric airflow of $3,500 \mathrm{cfm}$ is exhausted through the process cells); the maximum airflow through each cell is $500 \mathrm{cfm}$ (which is not the normal configuration but can occur when both valves of the exhaust ductwork are opened and airflow passes through two HEPA filters rather than one).

The $\mathrm{K} 3$ supply system is designed to maintain temperature comfort levels in both summer and winter. The total design volumetric airflow supplied to the canyon and process cells is $6,550 \mathrm{cfm}$.

Steam preheat and reheat coils maintain indoor temperatures during the heating months, and a chilled water coil maintains indoor temperature during the cooling months. Each process cell has two chilled water cooling coils to maintain temperatures below $120^{\circ} \mathrm{F}$.

\section{DISCUSSION}

\section{Requirements to Determine Airflows and Pressures}

Volumetric airflow aids in controlling both temperature and pressure requirements. Activities in the canyon are minimal because the WESF is not currently processing cesium and strontium. The existing temperatures values for maintaining human comfort levels in the canyon and the cooling requirements for maintaining cell processing temperatures are no longer necessary. The $\mathrm{K} 3$ ventilation system may be modified to reduce the existing volumetric airflow capabilities.

Determining the theoretical amount of volumetric airflow required for the heating or cooling requirements of the canyon is fundamental; calculating the pressure that would result at these airflows is subjective. This is due to the unknowns of actual openings and penetrations in the canyon. To collect this information and to assume that all penetrations have been identified and then to calculate the square footage of these penetrations would be time consuming and not cost effective.

\section{Canyon and Process Cells Airflow}

The airflow to both the canyon and the process cells can be reduced to a level that will maintain required airflow within the canyon and process cells. The exhaust system should still maintain the capability of permitting full flow, if required. The volumetric airflow which was measured in November 1996, was approximately $5,725 \mathrm{scfm}$. 
Essential drawings depict that approximately $5,000 \mathrm{cfm}$ is required for maintaining confinement when the process celis coverblocks are removed. This quantity of airflow can be used as a basis for determining the total airflow required for the $K 3$ exhaust system. The original design required a fan at $6,875 \mathrm{cfm}$ at $16-\mathrm{in}$. wg using a $30-\mathrm{hp}$ motor. The fan(s) has been replaced since then.

The vendor fan submittal data list the replacement fans at $8,500 \mathrm{cfm}$ at 28 -in. $\mathrm{wg}$ using a $60-h p$ motor. The additional fan capacity and static pressure requirements was added to allow operation of the system during a clean out of the $K 3$ exhaust duct and the increased differential pressure loss across the moisture laden demister pads. The de-entrainer was installed to eliminate entrained water vapor in the gas stream and to protect the HEPA filters from water collecting on media which could create a high differential pressure and possibly rupture the filter media. The entrained water vapor was created by water sprayed into the cells for decontamination purposes as well as the out gassing of the steam operated sump jets.

The fan capacity of $8,500 \mathrm{cfm}$ (maximum) was required to produce a specific velocity across the demister pad to permit the capture of the water droplets of certain particle size. The demister pad design requires three mechanisms to separate entrained moisture: inertia, diffusion, and direct interception.

The pressure drop across the demister pad is very important and is usually low. The pressure drop is affected by both gas and liquid flow rates. Gas flow through the dry demister pad is predominantly turbulent. The pressure drop increases across the pad when the entrained moisture rates increase. When this occurs, a greater portion of the voids within the pad is unavailable for the gas flow due to the presence of liquid in the voids.

At very low gas stream velocities, small droplets drift through the mesh avoiding the wire mesh filaments, resulting in re-entrainment. The electric heaters supplied with the de-entrainer assembly reduce relative humidity but do not eliminate water droplets from the gas stream, and also serves to evaporate any additional moisture which could remain in the demister pads.

It is assumed for this report that decontamination of the process cells will not be required after the decoupling project. Therefore, the airflow will be based on the confinement requirement of $5,000 \mathrm{cfm}$. If further processing and decontamination is necessary, the maximum airflow of $8,500 \mathrm{cfm}$ should be the basis for the airflow requirements.

Preliminary assumptions agreed with the original static pressure requirements listed on the HVAC equipment drawing $(\mathrm{H}-2-66534)$. Listed below are the assumptions for the static pressure requirements: 


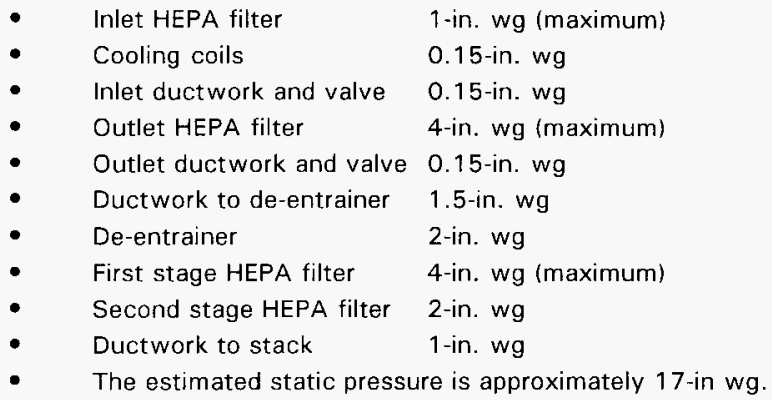

Between the original airflow of $6,875 \mathrm{cfm}$ and the $5,000 \mathrm{cfm}$ for confinement during coverblock removal, a nominal airflow of $6,000 \mathrm{cfm}$ can be employed as the new airflow criteria for the $\mathrm{K} 3$ ventilation system since it is also close to the current operating airflow. The $6,000 \mathrm{cfm}$ of air may be split between the two fans. Each fan can be modified for $3,000 \mathrm{cfm}$ of standard air and can be operated in this mode for normal conditions with the other fan in a standby mode. If the total of $6000 \mathrm{cfm}$ is required, the standby fan can be energized and put into operation.

The reduced airflow will also extend the life of both the in-cell HEPA filters and the final two stages of HEPA filters. The underrating of HEPA filters will not have an adverse effect since nuclear grade HEPA filters are rated and tested at both $100 \%$ and $20 \%$ of rated airflow.

The $\mathrm{K} 3$ fans use a 60 -hp motor. Reducing the volumetric airflow to $3,000 \mathrm{cfm}$ at 17 -in. wg will reduce the motor requirement to approximately a 20 -hp motor. This will decrease energy consumption.

The velocity in the 24-in. diameter duct at the original design airflow would be approximately $2,200 \mathrm{ft}$ per minute (fpm). This is close to the recommended velocity of 2,500 fpm listed in the ERDA-76-21, "Nuclear Cleaning Handbook."

The velocity at $3,000 \mathrm{cfm}$ in the 24 -in. diameter duct is approximately $1000 \mathrm{fpm}$. The recommended velocity is required to prevent particles from settling in the ductwork. The reduced velocity is acceptable for the following reasons:

- The existing ductwork is contaminated.

- The in-cell HEPA filters are installed prior to being discharged into the main trunk of the ductwork.

- No processing will occur in the cells to produce additional airborne particulates. 


\section{K3 Supply System}

The $K 3$ supply fan $\mathrm{K} 3-6-1$ airflow can be reduced to $2,500 \mathrm{cfm}$ to correspond with the flowrate reduction of the $\mathrm{K} 3$ exhaust fans, assuming that approximately $500 \mathrm{cfm}$ will infiltrate into the canyon. Excessive negative pressure in the canyon may occur if both the $\mathrm{K} 3$ exhaust fans come on-line. Both fans should operate only during a coverblock removal. The supply air delivered to the canyon should be sufficient to prevent excessive negative pressure.

The flowrate reduction could be accomplished by changing the fan and/or the motor sheaves, or by allowing the air to infiltrate from the service and operating gallery areas. Infiltration from the service and operating galleries is less favorable since the canyon is contaminated and there is a possibility of backflow occurring, and an upset in zone pressure to the other areas is probable.

The K3-6-1 fan motor would not necessarily require changeout. Changing the fan or motor sheave is all that is required to reduce the volumetric airflow. The motor would not be harmed although it would not be as efficient as a reduced-sized motor.

The 7.5-hp fan motor could be replaced with a 1-hp motor which would operate more efficiently. This is based on the assumption that the static pressure would be less due to the change in the volumetric airflow. With this option, the motor would have to be increased when the airflow increases due to the coverblock removal. WESF personnel need to evaluate whether it is more efficient to replace the motor or to leave the motor in-place and only replace one of the sheaves.

Another option is to terminate the supply fan and allow the airflow to be drawn into the canyon through the K3-6-1 supply system by the negative pressure created by the operating $\mathrm{K} 3$ exhaust fan. This option would allow the existing fan components (motor and sheaves) to remain as is, but would permit the required airflow during coverblock removal without replacing the motor and or sheaves. Calculations should be performed to determine what pressure would occur in the canyon by using this option.

The $\mathrm{K} 3$ exhaust fans would need to compensate for the additional resistances created by the elimination of the supply fan.

Assumptions based on the fan laws are that if 3 -in. wg is required to deliver $6550 \mathrm{cfm}$ of standard air, then approximately 0.75 -in. $w g$ would be required to deliver $3000 \mathrm{cfm}$ of standard air with the same ductwork configuration and components. Accordingly, a negative pressure of -0.75 -in. wg would develop in the canyon since the canyon would act as a plenum unless there is sufficient flowpaths (penetrations) through the 
walls and roof area of the canyon that would increase the infiltration and reduce the pressure.

With the canyon at a -0.75-in. $\mathrm{wg}$, the process cells would be required to be at a greater negative pressure to prevent contamination from the process cells from migrating into the canyon. This pressure also would affect the service/operating galleries and the other surrounding areas. Maintaining this negative pressure in the canyon may not be advantageous for plant operations.

\section{Recommendations for the Reduction of Airflow}

The following items are recommended to reduce the airflow in the canyon and process cells (see Figure 2):

- Evaluate the current need for the de-entrainer to ensure that the reduction of airflow does not adversely effect the performance for moisture removal. The de-entrainer is only needed during a clean out of the $\mathrm{K} 3$ duct system.

- Perform static pressure calculations to determine resistance of airflow for both the K3 supply and exhaust systems. Rough assumptions were made that the existing exhaust fans motors can be reduced from $60 \mathrm{hp}$ to approximately $20 \mathrm{hp}$.

- The existing fans can remain in-place and do not require replacement other than replacing the fan wheels which can be accomplished in the field.

- Reduce the airflow of exhaust fans K3-7-1 and K3-7-2 to 3,000 scfm of air.

- Reduce the supply airflow to $2,500 \mathrm{scfm}$ of air and assume approximately $500 \mathrm{scfm}$ of outside air infiltration to the canyon. Replace the existing motor with a motor sized according to the new requirements. Rough assumptions indicate that the existing 7.5-hp motor can be replaced with a 1-hp motor based on using the fan laws and assuming that the existing duct configuration and components remain the same.

- Since processing will no longer be a function in the cells, cell temperatures are not a concern. Using the total airflow of $3,000 \mathrm{cfm}$, the airflow may be divided by utilizing $1,000 \mathrm{cfm}$ to the process cells and $2,000 \mathrm{cfm}$ to the canyon area.

- Prepare a work plan to empirically test the reduced airflow rates prior to incorporating the recommended changes. The work plan should include methods for measuring and recording airflow and pressure for the canyon, 
process cells, and surrounding pressure zones such as the service and operating galleries.

- Perform an engineering study to determine the feasibility of replacing the $\mathrm{K} 3$ below grade remote handling HEPA filters with an above grade HEPA filter housing at the reduced airflow rate. The housing should have the capability of bag in and bag out HEPA filters. This could be a cost saving feature if decontamination of the cells and $\mathrm{K} 3$ ductwork is practical.

\section{Canyon and Process Cells Temperature Requirements}

The purpose of the canyon is to access the removable coverblocks of the process cells and the truckport. A remotely-operated 15 -ton crane that travels the full length of the canyon is provided for removing the coverblocks and equipment. A decontamination and maintenance area for the crane is located the east end of the canyon.

There is no temperature-sensitive equipment in the canyon and continued habitation by personnel is not required. During heating months, temperature requirements for personnel comfort is not necessary. During the summer months maintenance can be scheduled at a time of day when temperature are reasonable to prevent uncomfortable conditions for personnel. Inside temperatures should be maintained to prevent liquid effluents from freezing. U.S. Department of Energy DOE Order 6430.1A, Table 1550-1.2.2, "Inside Design Temperatures," states that an unoccupied storage area is determined by project criteria. An occupied storage area is to be maintained at $55^{\circ} \mathrm{F}$.

Since there is no criteria in DOE 6430.1 A for a canyon area temperature, it is assumed that the criteria for an occupied storage space can be applied to the canyon. It is reasonable to use a temperature from $45^{\circ} \mathrm{F}$ to $50^{\circ} \mathrm{F}$ for an inside temperature during the heating months.

The process cells contain chilled water coils to remove approximately 7200 Btuh produced in the cells and to maintain a cell temperature below a maximum value of $120^{\circ} \mathrm{F}$. Currently, no processing is being performed in the cells, therefore, cooling is not required and specific temperature criteria are not necessary other than a possible airflow requirement if capsules are stored in F-cell.

\section{Heating and Cooling Recommendations for the Canyon and Process Cells}

- $\quad$ Reduce canyon temperature to $45^{\circ} \mathrm{F}$ for heating months.

- Replace the existing steam coils with electric resistance heating. The power consumption saved by reducing the motor from $60 \mathrm{hp}$ to $20 \mathrm{hp}$ for exhaust 
fans $K 3-7-1$ and $K 3-7-2$ can be applied to the electric resistance heating for the canyon area.

- Eliminate the chilled water to chilled water coil K3-3-1 in the K3 supply system.

- Eliminate the chilled water to chilled water coils K3-3-2 through K3-3-15 in the process cells.

- Determined which pumps (K5-17-1, K5-17-2, or K5-17-3) can be put in a laid-up mode. Presently, the pumps are alternated on a weekly basis. Evaluate system at reduced water flow rates.

- Ensure that all chilled water is drained from the chilled water coils and from the associated $\mathrm{K} 3$ piping. This will also prevent the possibility of a leak contaminating the pool cells.

- Locate a point in the chilled water piping configuration that is the main header leading to the cooling coils. Disconnect the header from a connecting flange and install a blind flange to isolate the header from the remainder of the chilled water system.

- Record, list, and tag as "Out of Service" affected equipment and instrumentation where practical.

\section{Operating Pressures for the Canyon and Process Cells}

During normal operating conditions, the canyon pressure is maintained at a minimum differential of -0.2 -in. wg relative to the operating gallery. The current minimum pressures in the process cells are maintained at a negative pressure relative to the operating gallery and are as follows:

A cell: -0.8 -in. wg

A cell hood: -1.10 -in.wg

B cell: -3.0 -in. wg

C cell: -3.0 -in. $w g$

$D$ cell: -2.8 -in. wg

E cell: -2.8 -in. $w g$

$F$ cell: -1.25 -in. $w g$

G cell: -0.8 -in. wg

Process cells $F$ and $G$ can be maintained at the present operating pressures or at facility minimum operating pressures. Airflow from $E$ cell through $B$ cell can be cascaded to A cell and exhausted through A cell HEPA filters. The pressure would 
correspond to the direction of the cascading airflows (see Figure 3 for cell arrangement).

\section{Recommendations for Canyon and Process Cells Pressures}

- Locate and seal all potential leak paths in the canyon walls and roof that would prevent a minimum negative pressure of -0.2 -in. $w g$ relative to the operating gallery from being achieved.

- Prepare an operations test procedure (OTP) to operate the $K 3$ ventilation system at the recommended reduced airflows to ensure that required pressures are attained.

- The existing minimum negative pressures for $F$ cell, $G$ cell, and the canyon should be maintained.

- Pressures in the remaining cell will be maintained in the direction of the airflow ( $A$ cell being at the highest relative to $B, C, D$, and $E$ cells). The actual cell pressure to be established by facility personnel.

- The supply air valves to the cells will have to be adjusted to accommodate the desired airflows.

\section{In-Cell HEPA Filtration}

When processing cesium and strontium, in-cell HEPA filtration was initially provided for the minimization of ductwork contamination and the loading of the final two stages of HEPA filters. The in-cell HEPA filters are not considered a third stage of HEPA filtration or a radiological control barrier. Since future processing is not anticipated, and to minimize waste, the necessity for in-cell HEPA filtration is questioned.

The existing in cell HEPA filters have been in service since November of 1989 and currently have not reached the required differential pressure for filter replacement. The requirement for HEPA filter replacement based on differential pressure is between 4 to $5 \mathrm{in}$. water gage $(\mathrm{wg})$. HEPA filters maximum tested design differential pressure is $10 \mathrm{in.} w g$ at their design specific volumetric airflow. One of the primary reasons for replacing HEPA filters between the 4 to 5 in. wg range is based on economic reasons, i.e, higher the resistance requires greater fan horsepower. 
The following table list the current differential pressure for the in-cell HEPA filters:

\begin{tabular}{|c|c|c|}
\hline CELL & EAST & WEST \\
\hline$A$ & $0.0^{\prime \prime} \mathrm{wg}^{*}$ & $1.8^{\prime \prime} \mathrm{wg}$ \\
\hline$B$ & $0.4^{\prime \prime} \mathrm{wg}$ & $1.4^{\prime \prime} \mathrm{wg}$ \\
\hline$C$ & $2.5^{\prime \prime} \mathrm{wg}$ & $3.3^{\prime \prime} \mathrm{wg}$ \\
\hline$D$ & $1.0^{\prime \prime} \mathrm{wg}$ & $0.6^{\prime \prime} \mathrm{wg}$ \\
\hline$E$ & $1.1^{\prime \prime} \mathrm{wg}$ & $1.6^{\prime \prime} \mathrm{wg}$ \\
\hline$F$ & $0.2^{\prime \prime} \mathrm{wg}$ & $0.0^{\prime \prime} \mathrm{wg}^{*}$ \\
\hline$G$ & $0.6^{\prime \prime} \mathrm{wg}$ & $0.0^{\prime \prime} \mathrm{wg}^{*}$ \\
\hline
\end{tabular}

* = Damper in closed position.

It is assumed that the HEPA filters are performing at their design airflow rate of $250 \mathrm{cfm}$. In actual operation the airflow rate my be less than the assumed $250 \mathrm{cfm}$. In the case of " $\mathrm{C}$ " cell the airflow is greater to create a pressure gradient towards "C" cell.

HEPA filter differential pressure is created by having particulate accumulating on the filter medium, bridging the filter medium, thus reducing the surface area, causing the differential pressure. The amount and size of particulate(s) varies with the constituent's of the gas stream, the process being performed, and the transport velocity within the cells.

Obviously, if the gas stream is clean the HEPA filters can last indefinitely, conversely if the gas stream is heavily contaminated with particulate the HEPA filters would require changing quite frequently.

After removing the existing waste from the celis, no debris or activity is expected in the cells that would either create new, or disturb existing surface contamination which would result in producing airborne particulate(s), causing the HEPA filter(s) to load. In addition the volumetric airfiow within the cells does not produce sufficient transport velocities that would cause the particulate(s) to become airborne and collect on the HEPA filters medium. Also the inlet air supply to the cells are HEPA filtered, the cells should be remain relatively clean in regards to airborne particulate loading of the HEPA filters. 
To accurately determine the mass loading of a HEPA filter and predict the change-out frequency, specific information is required. The information that is required includes, the mass flow rate in grams per minute (of the particulate(s) in the cells), the particle mass median diameter, and a density in grams per cubic centimeter. The other information such as HEPA filter media in square feet, gas velocities, volumetric airflow, pressure drops, etc, can be easily obtained.

The following is an example of the amount of particulate it would take to create a differential pressure of 3 " wg in seven years. The $3^{\prime \prime} \mathrm{wg}$ differential pressure is based upon the HEPA filter is installed with a clean differential pressure drop of 1 " $\mathrm{Wg}$ and replaced when pressure drop is $4 " \mathrm{wg}$.

The existing in-cell HEPA filter(s) size is $12^{\prime \prime} \times 12^{\prime \prime} \times 11.5^{\prime \prime}$ having between 50 and $60 \mathrm{sq}$. $\mathrm{ft}$ of filter media. The " $\mathrm{C}$ " cell HEPA filter, according to the table is close to the 4" wg replacement requirement and will be used as the example.

To approximate the amount of particulate the existing "C" HEPA filter develop during the past seven years of service, certain assumptions were made. A mass median particle diameter of 2 micro meters, and a density of 2.6 grams per cubic centimeter were used as assumptions. Based on this assumed data, the HEPA filter mass accumulation of particulate would be 475 grams at a mass flow rate of 0.000129 grams per minute. This is only an example of what may be present and is not intended to represent actual conditions, other densities and particle diameter would produce a different mass flow rate.

If pertinent to the facility's needs, the inlet flows to the cells could be measured. One method to accomplish this would be to measure airflow at the inlet HEPA filters. These findings could characterize that the existing pressure differential (C-cell) is either caused by particulate or excessive airflow.

To establish a baseline reference point after the cells have been cleaned of waste products, it is recommended that the existing in-cell HEPA filters be replaced with clean HEPA filters.

\section{Recommendation for the In-Cell HEPA Filters}

- Although processing cesium and strontium is no longer a function of the WESF, support for a capsule failure recovery program should be considered. The following items are recommended:

- Retain the in-cell HEPA filters.

- Replace all existing in-cell HEPA filters. 
- $\quad F$ and $G$ cells would remain as configured, having an exhaust flowrate of $250 \mathrm{cfm}$ through one set of HEPA filters and the other set of HEPA filters isolated and in a standby mode.

- Isolate the pass-through from $F$ cell to $E$ cell.

- Remove pass-through doors between $C$ and $D$ cells and $B$ and $A$ cells.

- Isolate all HEPA filters for E, D, C, and B cells by closing the butterfly valves for the HEPA filters of these cells.

- The reduced airflow will cascade through the pass-throughs of $E, D, C$, and $B$ cells to A cell, and exit through A cell HEPA filters and A cell hood HEPA filters.

\section{INSTRUMENTATION}

The existing instrumentation for the $\mathrm{K} 3$ system should be maintained in the current configuration. During testing of the $\mathrm{K} 3$ system for reduced airflow, ranges of certain instruments, i.e., pressure alarms, should be monitored to ensure that the proper set points have and can be achieved.

The existing stack monitoring system (isokinetic probe) will be replaced with a new probe sized for the new reduced airflow.

\section{ASSUMPTIONS}

For this report the following assumptions were made:

- $\quad F$ and $G$ cells will be maintained for future capsule inspection.

- $\quad$ All other process cells will not be required for processing.

- Criteria for maintaining cell temperature are not a requirement.

- Entrance to the canyon will only be for routine crane maintenance.

- Temperature for personnel comfort is not required and crane maintenance can be scheduled to minimize uncomfortable conditions for operational personnel. 
- The $\mathrm{K} 3$ ventilation system should be capable of being reactivated for future facility operation.

- $\quad$ Since the WESF is not scheduled for shutdown until the year 2017, temporary heating system for the canyon was not considered.

\section{REFERENCES}

\section{Documents}

1. Letter of Instruction, F. H. Lee, B\&W Hanford Company, to W. A. Holstein, Fluor Daniel Northwest, "Waste Encapsulation and Storage Facility Decoupling Project, Waste Minimization Activities," Document No. 2C-96-036-01, October 22, 1996.

2. Air Movement and Control Association, Inc. (AMCA)

AMCA 99-86, "Standards Handbook"

AMCA 201-90, "Fan Application Manual - Fans and Systems"

AMCA 210-85, "Certified Ratings Program Air Performance"

3. American Society of Heating, Refrigerating and Air-Conditioning Engineers (ASHRAE)

Applications

Fundamentals Handbook

Systems and Equipment Handbook

4. American Society of Mechanical Engineers (ASME)

ASME N509, "Nuclear Power Plant Air-Cleaning Units and Components" ASME N510, "Testing of Nuclear Air Treatment Systems"

5. ERDA 76-12, "Nuclear Cleaning Handbook"

6. Supporting Document, "Waste Encapsulation and Storage Facility Safety Analysis Report, "WHC-SD-WM-SAR-005, Rev 12.

7. U.S. Department of Energy Order 6430.1A, "General Design Criteria"

\section{Drawings}

H-2-66553, "HVAC Flow Diagram"

$\mathrm{H}-2-66534$, "HVAC Equipment Schedules"

$\mathrm{H}-2-66400$, "Drawing Index" 


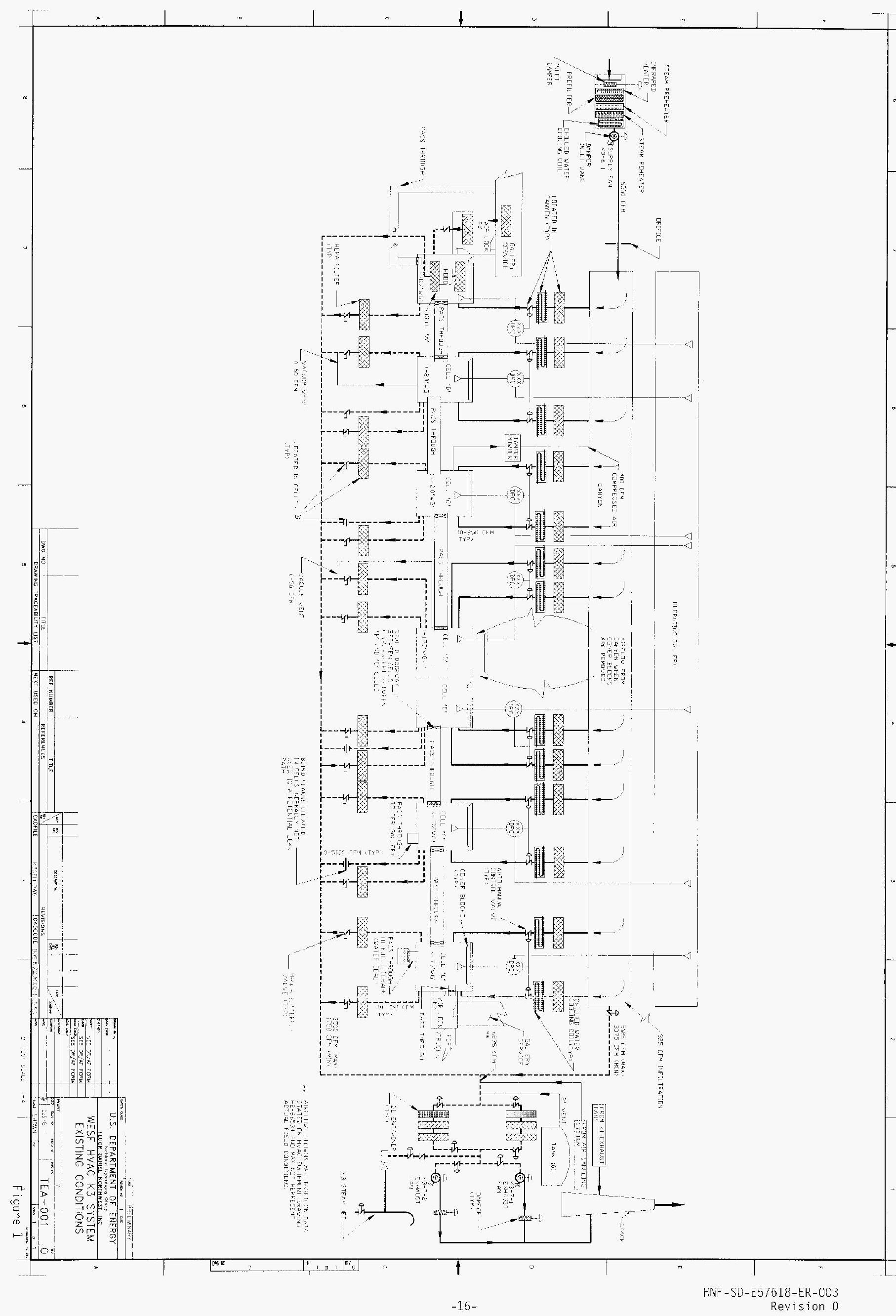




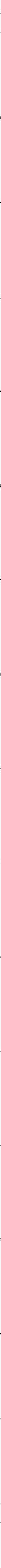




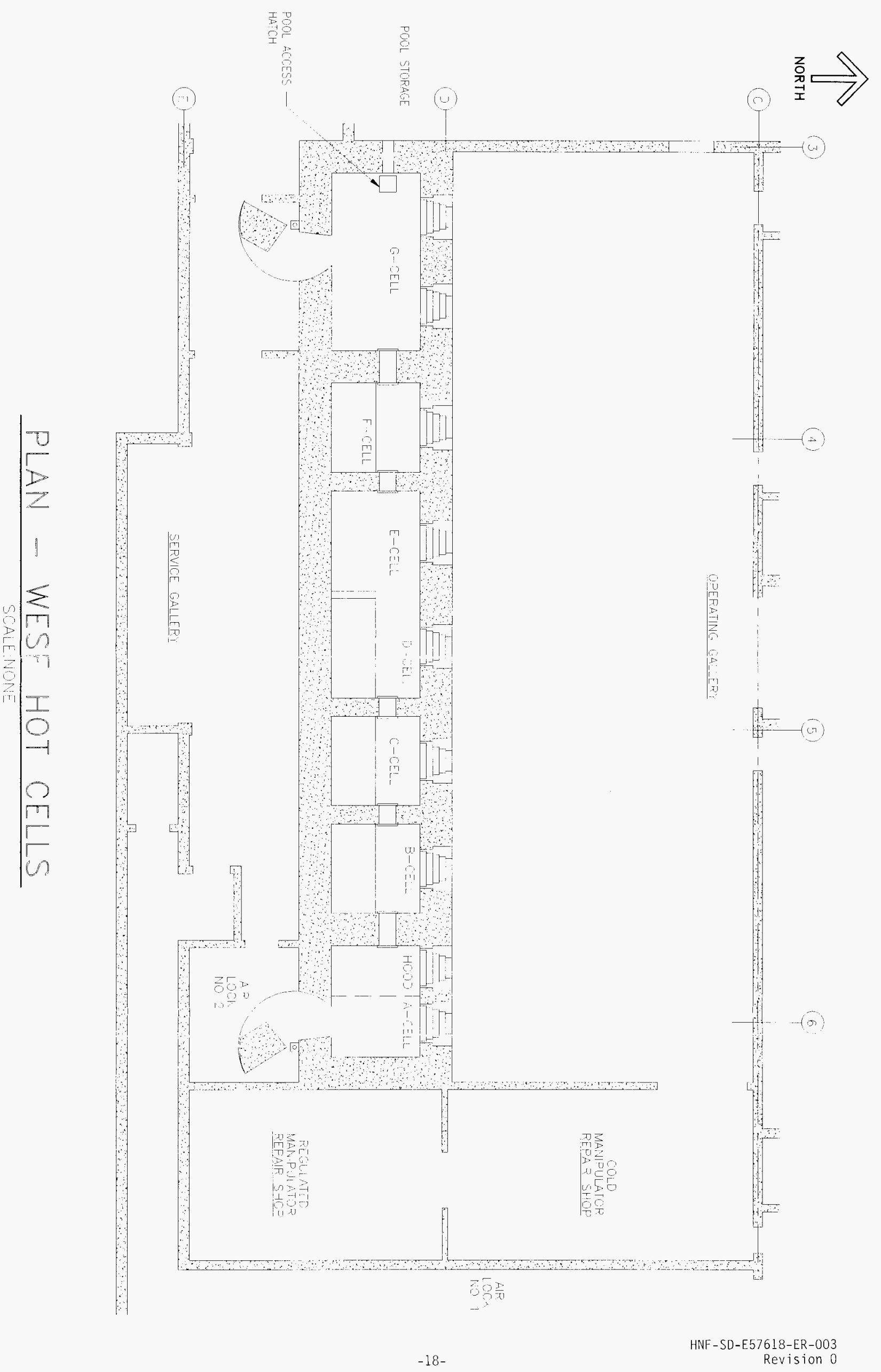

